Arq. Bras. Med. Vet. Zootec., v.69, n.2, p.299-304, 2017

\title{
Retrospective study of Bovine herpesvirus 5 meningoencephalitis in cattle from São Paulo State, Brazil
}

\author{
[Estudo retrospectivo de meningoencefalite por herpesvírus bovino-5 em bovinos \\ do estado de São Paulo, Brasil] \\ D.Q. Cagnini ${ }^{1}$, D.G.A. Andrade ${ }^{1}$, P.H.J. Cunha ${ }^{2}$, J.P. Oliveira-Filho ${ }^{1}$, R.L. Amorim ${ }^{1}$, \\ A.A. Alfieri $^{3}$, A.S. Borges ${ }^{1 *}$ \\ ${ }^{1}$ Faculdade de Medicina Veterinária e Zootecnia - UNESP - Univ Estadual Paulista - Botucatu, SP \\ ${ }^{2}$ Escola de Veterinária e Zootecnia - Universidade Federal de Goiás- Goiânia, GO \\ ${ }^{3}$ Universidade Estadual de Londrina-UEL-Londrina, PR
}

\begin{abstract}
Meningoencephalitis caused by Bovine herpesvirus 5 (BoHV-5) is an important neurological disease that affects Brazilian cattle herds. The present study investigated the presence of BoHV-5 DNA in cattle diagnosed with meningoencephalitis at Faculdade de Medicina Veterinária e Zootecnia, UNESP - Univ Estadual Paulista from 1980 to 2009. The records obtained from the Large Animal Internal Medicine Service and the Animal Pathology Service were reviewed to identify clinical and epidemiological data from cattle with neurological signs. Excluding rabies cases, we found 115 cases of cattle with neurological signs that had been necropsied. Non-suppurative meningoencephalitis was diagnosed in 28 animals of the 115 initially selected based on histopathological examination of brain tissues. Of these 28 animals, 15 (54\%) were positive for BoHV-5 DNA by polymerase chain reaction (PCR) of formalin-fixed paraffin-embedded (FFPE) brain samples. PCR target was 159-bp fragment from the BoHV-5 glycoprotein C gene. The oldest case identified in the present study was from 1988. PCR was a good tool for the diagnosis of BoHV-5 DNA extracted from FFPE tissues, allowing retrospective studies of samples stored for more than 20 years.
\end{abstract}

Keywords: cattle diseases, herpesvirus 5 bovine, meningoencephalitis, pathology, polymerase chain reaction

\section{RESUMO}

A meningoencefalite por herpesvírus bovino-5 (BoHV-5) é uma doença neurológica importante no rebanho bovino brasileiro. Este estudo tem por objetivo verificar a presença do DNA de BoHV-5 em bovinos diagnosticados com meningoencefalite na Faculdade de Medicina Veterinária e Zootecnia da Universidade Estadual Paulista, entre os anos de 1980 e 2009. Foram revisados os arquivos do Serviço de Clínica de Grandes Animais e da Patologia Animal em busca dos dados clínicos e epidemiológicos de bovinos com sinais neurológicos. Excluídos os casos de raiva, foram encontrados 115 casos de bovinos com sinais neurológicos, que foram necropsiados. O exame histopatológico realizado nos tecidos encefálicos desses animais constatou lesões de meningoencefalite não supurativa em 28 animais. Destes, em 15 (54\%) casos foi identificada a presença do DNA de BoHV-5 por meio de PCR realizada em amostras de tecido encefálico fixadas em formalina e incluidas em parafina (FFPE). O alvo da PCR foi um fragmento de $159 \mathrm{pb}$ do gene da glicoproteina $C$ do BoHV-5. O caso mais antigo identificado neste estudo foi de 1988. A PCR apresentou-se como boa ferramenta para o diagnóstico do DNA de BoHV-5 extraído de tecidos FFPE, possibilitando estudos retrospectivos e diagnóstico de amostras com mais de 20 anos de armazenamento.

Palavras-chave: doenças dos bovinos, herpesvirus bovino 5, meningoencefalite, patologia, reação em cadeia da polimerase

Recebido em 23 de maio de 2016

Aceito em 13 de setembro de 2016

*Autor para correspondência (corresponding author)

E-mail: asborges@fmvz.unesp.br 


\section{INTRODUCTION}

Bovine meningoencephalitis is a viral infection mainly caused by Bovine herpesvirus 5 (BoHV5 ), previously classified as BoHV-1.3, which is an enveloped, double-stranded DNA virus belonging to the family Herpesviridae, subfamily Alphaherpesvirinae, genus Varicellovirus (Roizman et al., 1992). Meningoencephalitis primarily occurs in calves, causing death or low morbidity and high mortality outbreaks (Rissi et al., 2006, 2008). The clinical sings can include depression, nasal and ocular discharge, grinding of teeth, circling, blindness, nystagmus, incoordination, head pressing, falls, recumbency, opisthotonus and convulsions (Rissi et al., 2006). The disease is not seasonal and has no predilection for breed or sex (Barros et al., 2006), and outbreaks have been associated with stressful factors such as weaning, vaccinations, transportation or changes in feeding (Rissi et al., 2008).

At necropsy, gross lesions may not be seen or they are restricted to the brain and are characterized by hyperemia of the leptomeninges with or without malacia. Histologically, the key general lesion of affected cattle is nonsuppurative meningoencephalitis. The definitive diagnosis can be established through the association of clinical and epidemiological data with the presence of inclusion bodies in the histological evaluation (Barros et al., 2006), virus isolation in cell culture, and identification of viral proteins and the viral genome by immunohistochemical and molecular techniques, respectively (Cagnini et al., 2015). However, virus isolation is not always possible because of the distance between the site where the sample was collected and the reference laboratories and the time elapsed between the animal's death and sample collection. Immunohistochemistry and polymerase chain reaction (PCR) are good diagnostic tools. Furthermore, these techniques may be successfully applied to formalin-fixed paraffin-embedded tissues (FFPE) (Ferrari et al., 2007), thereby enabling retrospective studies of histopathological archives.

The presence of BoHV-5 DNA in paraffin blocks of central nervous system (CNS) tissues collected from cattle diagnosed with meningoencephalitis admitted to the Veterinary Hospital of Faculdade de Medicina Veterinária e
Zootecnia (FMZV), UNESP - Univ Estadual Paulista, Campus Botucatu, between 1980 and 2009, was assessed in the present study.

\section{MATERIALS AND METHODS}

A survey of cases of cattle diagnosed with neurological disorders and admitted to the Large Animal Internal Medicine Service and the Animal Pathology Service of FMVZ from 1980 to 2009 was performed. The record books of both services were used; cases were selected and rabies-positive cases were excluded from the study. Additionally, the records of the Veterinary Hospital of FMVZ were searched to access the clinical, anatomopathological and epidemiological data from the animals.

Subsequently, the archives of paraffin blocks from the Veterinary Pathology Service of FMVZ were searched to obtain paraffin blocks from animals with suggestive signs of neurological disease. These blocks were used to prepare histological slides for haematoxylin and eosin (H\&E) staining. Based on the histopathological evaluation, the cases were classified as suggestive of meningoencephalitis caused by BoHV-5. Cases that showed non-suppurative meningoencephalitis with or without malacia were selected for subsequent DNA extraction from FFPE tissues and PCR.

Initially, one brain region was selected for DNA extraction and PCR per animal. For this purpose, we chose the block with more severe histopathologic lesions and gave preference to blocks containing the cerebral cortex. In the case of a negative PCR, a new DNA extraction was prepared from another paraffin wax block of brain, and a new PCR was performed.

To prevent contamination between DNA extractions from cerebrum samples, the microtome was cleaned before and between sections of the paraffin blocks and a single histological razor and new pair of disposable gloves were used for each block. DNA extractions were performed using the QIAamp ${ }^{\circledR}$ DNA FFPE Tissue Kit (QIAGEN ${ }^{\circledR}$, Germany) according to the manufacturer's protocol. DNA quality and quantity were assessed using a NanoDrop ${ }^{\mathrm{TM}}$ Spectrophotometer (NanoDrop 1000 Spectrophotometer, Thermo Scientific ${ }^{\mathrm{TM}}$, USA). 
The DNA samples were subjected to PCR using the B5 and Bcon primers, which amplify a 159bp fragment from the BoHV-5 glycoprotein C gene as previously described by Claus et al. (2005).

DNA from the BoHV-5 AA PAR strain (Souza et al., 2002) provided by the Laboratory of Animal Virology, Department of Veterinary Preventive Medicine, Universidade Estadual de Londrina was used as the positive control in all PCR runs. Bovine $\beta$-actin was used as an internal control in all the PCR reactions to evaluate the DNA extraction efficiency and DNA integrity (Cagnini et al., 2015).

The PCR products were analysed by electrophoresis on a $1.5 \%$ agarose gel stained with GelRed ${ }^{\mathrm{TM}}$ (Biotium, USA), visualized under UV light and photodocumented using ImageQuant $^{\circledR}\left(\mathrm{GE}^{\circledR}\right.$ Healthcare, UK). The PCR results (positive or negative) were compared with the presence or absence of malacia by Fisher's exact test using GraphPadInStat $3^{\circledR}$ software for Windows (GraphPad Software, USA).

All the procedures were previously approved by the Universidade Estadual Paulista (UNESP) Institutional Animal Care and Use Committee $(91 / 2009)$.

\section{RESULTS AND DISCUSSION}

In the present retrospective study, 115 cases of necropsied cattle with neurological abnormalities were identified, excluding rabies-positive cases. Of the 115 cases, 69 had paraffin CNS tissue blocks stored in the Pathology Service. Of these, 61 cases had CNS histological alterations. A total of 33 cases were diagnosed as polioencephalomalacia $(29 / 33)$ or bacterial meningitis/meningoencephalitis (4/33). The remaining cases $(28 / 61)$, which presented nonsuppurative meningoencephalitis, were subjected to PCR. BoHV-5 DNA was detected in 54\% $(15 / 28)$ of these samples.

The average age of the animals that were PCR positive for BoHV-5 DNA was 17 months, with a range from 7 to 36 months. Although meningoencephalitis caused by BoHV-5 primarily affects young animals, it may also affect adults (Salvador et al., 1998; Elias et al., 2004; Rissi et al., 2008; Aquino Neto et al., 2009; Cunha et al., 2009). Indeed, BoHV-5 has been described in animals from 1 (Rissi et al.,
2008) to 60 months of age (Salvador et al., 1998; Aquino Neto et al., 2009).

In the present study, a greater percentage of males $(11 / 15=73 \%)$ than females $(4 / 15=27 \%)$ was positive for BoHV-5 DNA. However, this result is likely a sampling bias because meningoencephalitis caused by BoHV-5 does not show predilection for sex (Barros et al., 2006). The BoHV-5-positive animals were from 15 different farms located in several cities of the Midwest region of São Paulo State (Brazil). Most farms were in the Botucatu region, probably due to the proximity to the Veterinary Hospital of FMVZ. According to Elias et al. (2004), meningoencephalitis caused by BoHV-5 had no predilection for breed and featured variable morbidity. This characteristic was evidenced in the present study, in which the disease affected animals of different breeds and the morbidity rate ranged from $0.005 \%$ to $10 \%$.

The oldest case identified in the present study was from 1988, which was a few years prior to the first report of meningoencephalitis caused by BoHV-5 in the state of São Paulo, Brazil (Salvador et al., 1998). However, this case was contemporary to the first reports of the disease in Brazil, which occurred in Rio Grande do Sul State and was first attributed to Bovine herpesvirus 1 (BoHV-1) (Weiblen et al., 1989; Riet-Correa et al., 1989) but was later renamed BoHV-5 in 1992 (Roizman et al., 1992).

Previous studies reported that primary histological lesions of BoHV-5 encephalitis are non-suppurative meningoencephalitis with mononuclear perivascular cuffs, cerebrocortical necrosis, oedema, congestion, haemorrhage, focal to diffuse gliosis, and neuronophagia (Rissi et al., 2006; Arruda et al., 2010; Cagnini et al., 2015). Similar lesions were found in the present study in all BoHV-5 PCR positive animals, although inclusion bodies were not observed in 9 positive cases. The histopathological lesions varied in intensity depending on the CNS region and/or animal sampled. Similar alterations were found in suspected cases that were negative for BoHV-5 by PCR.

Among the 15 PCR positive samples, malacia was observed in $87 \% \quad(13 / 15)$ of them. Comparatively, the pathological state was only detected in $15 \%(2 / 13)$ of the PCR-negative cases. According to Fisher's exact test, there was 
an association between malacia and positivity for BoHV-5 ( $\mathrm{P}=0.0004)$. Cagnini et al. (2015) described histological changes in $108 \mathrm{CNS}$ areas of 6 calves experimentally infected with BoHV-5 and compared these changes with the PCR results. The authors found that PCR-positive areas displayed more severe lesions than PCRnegative areas (Cagnini et al. 2015). The lesion intensity was not classified in the present study.

The detection percentage of BoHV-5 by PCR in the FFPE brain samples of cattle with a histopathological diagnosis of non-suppurative meningoencephalitis is varied, as can be observed in the present study $(54 \%, 15 / 28)$ and in previous studies that detected BoHV-5 in $21.8 \%$ [7/32] (Ely et al., 1996), 66.6\% [2/3] (Gomes et al., 2002), 75\% [15/20] (Ferrari et al., 2007), 33.3\% [12/36] (Arruda et al., 2010) and $33.3 \%$ [5/15] of samples (Pedraza et al., 2010). The variation in the results exemplified above can be a result of tissue fixation process, which ensures proper morphological conservation but may affect the preservation of nucleic acids and negatively affect the PCR results (Barcelos et al., 2008). According to Karlsen et al. (1994), the fixation time causes DNA degradation and compromises the PCR results. Arruda et al. (2010) demonstrated that samples stored for more than 40 days in formalin had less PCRpositive results than samples stored for less than 40 days in formalin or frozen. Moreover, PCRnegative results may occur due to other factors, such as insufficient or absent viral DNA in the tissue, poor DNA extraction and the size of the amplified product in the FFPE samples (Arruda et al., 2010; Jacobs, 2012).

The medical records of the present study did not show the time elapsed between the animal's death and sample collection, the formalin fixation time or the use of buffered formalin. Some of these aspects may have contributed to the occurrence of PCR false-negative results in some of the cases with BoHV-5-suggestive lesions by histopathology. However, all DNA samples were positive for the bovine $\beta$-actin gene, which confirm the presence of DNA.

Taking into account the sample storage time, the amplicon size (159 bp) amplified by the B5 and Bcon primers likely contributed to the positive results because PCR with FFPE samples can rarely amplify amplicons longer than $300 \mathrm{bp}$ even when commercial extraction kits are used (Jacobs, 2012). For example, Alcântara et al. (2015) obtained different results by using the same FFPE sample but changing the amplicon size.

The telencephalon was described as the best sampling area for diagnostic purposes in BoHV5 -suspected cases because it presented more accentuated lesions and positive PCR areas than the other $18 \mathrm{CNS}$ areas evaluated in an experimental study (Cagnini et al., 2015). In the present study, telencephalon samples were not available for all suspected cases of BoHV-5, making it impossible to standardize the same areas for all evaluated animals; therefore, areas with more severe histopathological lesions were used.

The detection of BoHV-5 DNA by PCR alone does not confirm that the animals had the infection because the virus may be latent (Vogel et al., 2003). However, PCR-positive results for the partial sequence of the BoHV-5 glycoprotein $\mathrm{C}$ gene associated with clinical and epidemiological data suggest that the clinical cases assessed in the present study resulted from meningoencephalitis caused by BoHV -5 .

Another important factor considered in cases of PCR-negative results is that different etiological agents could cause similar microscopic changes. Rabies, malignant catarrhal fever, listeriosis, thromboembolic meningoencephalitis, astrovirus and other viruses that have been detected by metagenomics, and less commonly, meningoencephalitis caused by BoHV-1 must be considered in the differential diagnosis of BoHV5 (Rissi et al., 2006, 2008; Silva et al., 2007; Headley et al., 2012, 2014, 2015; Li et al., 2013; Wüthrich et al., 2016).

\section{CONCLUSION}

PCR on FFPE material was a good diagnostic method for suspected BoHV-5 cases, especially for archival material. Using this method, the epidemiology of past clinical cases could be better elucidated and inconclusive cases could receive a definitive diagnosis. This methodology provided additional knowledge on the natural history of the disease. 


\section{ACKNOWLEDGMENTS}

The authors thank the São Paulo Research Foundation (FAPESP) for granting a master's degree scholarship to the first author (process number 2008/07697-9) and a scientific initiation scholarship to the second author (process number 2010/00160-0). Thanks also to the National Council for Scientific and Technological Development $(\mathrm{CNPq})$ for productivity grants to Amorim, R.L., Alfieri, A.A. and Borges, A.S.

\section{REFERENCES}

ALCÂNTARA, B.K.; ALFIERI, A.A.; HEADLEY, S.A. et al. Molecular characterization of bovine Deltapapillomavirus (BPV1, 2, and 13) DNA in equine sarcoids. Pesqui. Vet. Bras., v.35, p.431-436, 2015. Available in: <http://www.pvb.com.br/pdf artigos/27-06-2015_13-23Vet\%201889_4098\% 20LD.pdf $>$. Accessed: mar 16, 2016.

AQUINO NETO, H.M.; CARVALHO, A.U.; FACURY FILHO, E.J. et al. Meningoencefalite por Herpesvirus bovino 5 em Minas Gerais: relato de caso clínico. Arq. Bras. Med. Vet. Zootec., v.61, p.1-5, $2009 . \quad$ Disponível em: $<$ http://www.scielo.br/pdf/abmvz/v61n1/v61n1a01.pdf >. Acessado em: mar 16, 2016.

ARRUDA, L.P.; NAKAZATO, L.; DUTRA, V. et al. Detecção molecular de herpesvírus bovino 1 e 5 em amostras de encéfalo conservadas em formol e emblocadas em parafina provenientes de bovinos com doença neurológica. Pesqui. Vet. Bras., v.30, p.646-650, 2010. Disponível em: $<$ http://www.scielo.br/pdf/pvb/v30n8/07.pdf>.

Acessado em: mar 16, 2016.

BARCELOS, D.; FRANCO, M.F.; LEÃO, S.C. Effects of tissue handling and processing steps on pcr for detection of Mycobacterium tuberculosis in formalin-fixed paraffin-embedded samples. Rev. Inst. Med. Trop. São Paulo, v.50, p.321-326, 2008. Available in: $<$ http://www.scielo.br/pdf/rimtsp/v50n6/v50n6a02.pdf >. Accessed in: mar 16, 2016.

BARROS, C.S.L.; DRIEMEIER, D., DUTRA, I.S.; LEMOS, R.A.A. Doenças do sistema nervoso de bovinos no Brasil. São Paulo:Agnes, 2006. 238p.

CAGNINI, D.Q.; CUNHA, P.H.J.; PANTOJA, J.C.F. et al. Histopathological, immunohistochemical, and molecular study of BHV-5 infection in the central nervous system of experimentally infected calves. Pesqui. Vet. Bras., v.35, p.337-343, 2015. Available in: $<$ http://www.scielo.br/pdf/pvb/v35n4/0100-736Xpvb-35-04-00337.pdf>. Accessed in: mar 16, 2016.
CLAUS, M.P.; ALFIERI, A.F.; FOLGUERASFLATSCHART, A.V. et al. Rapid detection and differentiation of bovine herpesvirus 1 and 5 glycoprotein $\mathrm{C}$ gene in clinical specimens by multiplex-PCR. J. Virol. Methods, v.128, p.183-188, 2005. Available in: <http://ac.elscdn.com/S0166093405001461/1-s2.0-

S0166093405001461-main.pdf?_tid=e2d7b62e-eb7911e5-b2b6-

00000aab0f27\&acdnat $=1458134623 \_b 913 a c 1 c 818783$ 7e55f7a680c21fcd5e>. Accessed in: mar 16, 2016.

CUNHA, P.H.J.; DELFIOL, D.J.Z.; CAGNINI, D.Q. et al. Identificação molecular do herpesvirus bovino tipo $5 \mathrm{em}$ um bovino confinado associado com diagnóstico diferencial laboratorial de outras causas de polioencefalomalacia. Ciênc. Anim. Bras., Supl.1, p.93-98, 2009.

ELIAS, F.; SCHILD, A.N.; RIET-CORREA, F. Meningoencefalite e encefalomalacia por Herpesvírus bovino-5: distribuição das lesões no sistema nervoso central de bovinos naturalmente infectados. Pesqui. Vet. Bras., v.24, p.123-131, 2004. Disponível em: $<$ http://www.scielo.br/pdf/pvb/v24n3/v24n3a03.pdf $>$. Acessado em: mar 16, 2016.

ELY, R.W.; d'OFFAY, J.M.; RUEFER, A.H.; CASH, C.Y. Bovine herpesviral encephalitis: a retrospective study on archived formalin-fixed, paraffin-embedded brain tissue. J. Vet. Diagn. Invest., v.8, p.487-492, 1996. Available in: $<$ http://vdi.sagepub.com/content/8/4/487.full.pdf $>$. Accessed in: mar 16, 2016.

FERRARI, H.F.; LUVIZOTTO, M.C.R.; RAHAL, P.; CARDOSO, T.C. Detection of bovine Herpesvirus type 5 in formalin-fixed, paraffin-embedded bovine brain by PCR: a useful adjunct to conventional tissuebased diagnostic test of bovine encephalitis. J. Virol. Methods, v.146, p.335-340, 2007. Available in: $<$ http://ac.els-cdn.com/S0166093407002893/1-s2.0S0166093407002893-main.pdf?_tid=5bbd0e30-eb7b$11 \mathrm{e} 5-9370-$

00000aab0f6b\&acdnat $=1458135255 \_446 e e 24 \mathrm{db} 91 \mathrm{~d} 9$ 7ac07f3df9f6a87a043>. Accessed in: mar 16, 2016.

GOMES, L.I.; ROCHA, M.A.; COSTA, E.A. et al. Detecção de herpesvírus bovino 5 (BoHV-5) em bovinos do sudeste brasileiro. Arq. Bras. Med. Vet. Zootec., v.54, p.217-220, 2002. Disponível em: $<\mathrm{http}$ ://www.scielo.br/scielo.php?script=sci_arttext\&p id=S0102-09352002000200014\&lng=en\&nrm=iso $>$. Acessado em: mar 16, 2016.

HEADLEY, S.A.; BRACARENSE, A.P.F.R.L.; OLIVEIRA, V.H.S. et al. Histophilus somni-induced thrombotic meningoencephalitis in cattle from northern Paraná, Brazil. Pesqui. Vet. Bras., v.35, p.329-336, 2015. Available in: $<$ http://www.scielo.br/pdf/pvb/v35n4/0100-736X-pvb35-04-00329.pdf $>$. Accessed in: mar 16, 2016. 
HEADLEY, S.A.; FRITZEN, J.T.T.; QUEIROZ, G.R. et al. Molecular characterization of encephalitic bovine listeriosis from southern Brazil. Trop. Anim. Health Prod., v.46, p.19-25, 2014. Available in $<$ https://link.springer.com/article/10.1007\%2Fs11250013-0441-0>. Accessed in: mar 16, 2016.

HEADLEY, S.A.; SOUSA, I.K.F.; MINERVINO, A.H.H. et al. Molecular confirmation of ovine herpesvirus 2-induced malignant catarrhal fever lesions in cattle from Rio Grande do Norte, Brazil. Pesqui. Vet. Bras., v.32, p.1213-1218, 2012. Available in:

$<$ http://www.scielo.br/pdf/pvb/v32n12/v32n12a01.pdf $>$. Accessed in: mar 16, 2016.

JACOBS, S. Sample processing considerations for detecting copy number changes in formalin-fixed, paraffin-embedded tissues. Cold Spring Harb. Protoc., v.2012, p.1195-1202, 2012. Available in: $<$ http://cshprotocols.cshlp.org/content/2012/11/pdb.ip0 71753.full.pdf + html $>$. Accessed in: $\operatorname{mar} 16,2016$.

KARLSEN, F.; KALANTARI, M.; CHITEMERERE, M. et al. Modifications of human and viral deoxyribonucleic acid by formaldehyde fixation. Lab. Invest., v.71, p.604-611, 1994.

LI, L.; DIAB, S.; McGRAW, S. et al. Divergent astrovirus associated with neurologic disease in cattle. Emerg. Infect. Dis., v.19, p.1385-1392, 2013. Available

$<$ http://wwwnc.cdc.gov/eid/article/19/9/pdfs/13-

0682.pdf>. Accessed in: apr 30, 2016.

PEDRAZA, F.J.; ALESSI, A.C.; BARBOSASTANCIOLI, E.F. Detection of bovine herpesvirus 5 (BoHV-5) in formalin-fixed, paraffin-embedded bovine brain by nested PCR in Colombian cattle. Rev. Colomb. Cienc. Pecu., v.23, p.292-298, 2010. Available in: $<$ http://www.scielo.org.co/scielo.php?script=sci_arttex t\&pid=S0120 -

06902010000300004\&lng=en\&nrm=iso $>$. Accessed in: $\operatorname{mar} 16,2016$.

RIET-CORREA, F.; VIDOR, T.; SCHILD, A.L.; MÉNDEZ, M.C. Meningoencefalite e necrose do córtex cerebral em bovinos causada por herpesvirus bovino-1. Pesqui. Vet. Bras., v.9, p.13-16, 1989.

RISSI, D.R.; OLIVEIRA, F.N.; RECH, R.R. et al. Epidemiologia, sinais clínicos e distribuição das lesões encefálicas em bovinos afetados por meningoencefalite por herpesvírus bovino-5. Pesqui. Vet. Bras., v.26, p.123-132, 2006. Disponível em: $<$ http://www.scielo.br/pdf/pvb/v26n2/a10v26n2.pdf $>$. Acessado em: mar 16, 2016.
RISSI, D.R.; PIEREZAN, F.; SILVA, M.S. et al. Neurological disease in cattle in southern Brazil associated with Bovine herpesvirus infection. J. Vet. Diagn. Invest., v.20, p.346-349, 2008. Available in: $<$ http://vdi.sagepub.com/content/20/3/346.full.pdf + ht $\mathrm{ml}>$. Accessed in: mar 16, 2016.

ROIZMAN, B.; DESROSIERS, R.C.; FLECKENSTEIN, B. et al. The family Herpesviridae: an update. Arch. Virol., v.123, p.425-449, 1992. Available

$<$ http://europepmc.org/abstract/MED/1562239>.

Accessed in: mar 16, 2016. SALVADOR, S.C.; LEMOS, R.A.A.; RIET-CORREA, F. et al. Meningoencefalite em bovinos causada por herpesvírus bovino-5 no Mato Grosso do Sul e São Paulo. Pesqui. Vet. Bras., v.18, p.76-83, 1998. Disponível

<http://www.scielo.br/pdf/pvb/v18n2/0898.pdf>.

Acessado em: mar 16, 2016.

SILVA, M.S.; BRUM, M.C.S.; LORETO, E.L.S. et al. Molecular and antigenic characterization of Brazilian bovine herpesvirus type 1 isolates recovered from the brain of cattle with neurological disease. Virus Res., v.129, p.191-199, 2007. Available in: <http://ac.elscdn.com/S0168170207002766/1-s2.0-

S0168170207002766-main.pdf?_tid=4a93a5c0-eb7f-

$11 \mathrm{e} 5$-a11e-

00000aab0f02\&acdnat $=1458136945 \quad 462 \mathrm{c} 8 \mathrm{f} 3 \mathrm{c} 3 \mathrm{cee} 45$

5ab96b0d5415275fc8>. Accessed in: mar 16, 2016.

SOUZA, V.F.; MELO, S.V.; SCHMIDT, C.S. et al. Caracterização de herpesvírus bovinos tipos 1 (BHV1) e 5 (BHV-5) com anticorpos monoclonais. Pesqui. Vet. Bras., v.22, p.13-18, 2002. Disponível em: $<$ http://www.scielo.br/pdf/pvb/v22n1/8866.pdf $>$.

Acessado em: mar 16, 2016.

VOGEL, F.S.F.; CARON, L.; FLORES, E.F. et al. Distribution of bovine herpesvirus yype 5 DNA in the central nervous system of latently, experimentally infected calves. J. Clin. Microbiol., v.41, p.4512-4520, $2003 . \quad$ Available in: $<$ http://jem.asm.org/content/41/10/4512.full.pdf + html >. Accessed in: mar 16, 2016.

WEIBLEN, R.; BARROS, C.S.L.; CANABARRO, T.F. Bovine meningoencefalitis from IBR virus. Vet. Rec., v.124, p.666-667, 1989.

WÜTHRICH, D.; BOUJON, C.L.; TRUCHET, L. et al. Exploring the virome of cattle with nonsuppurative encephalitis of unknown etiology by metagenomics. Virology, v.493, p.22-30, 2016. Available in: $<\mathrm{http} / / /$ www.sciencedirect.com/science/article/pii/S00 42682216300290>. Accessed in: apr 30, 2016. 